\title{
SISTEMATIZAÇÃO DO PROCESSO DE PROJETO PARA PRODUÇÃO DE ALVENARIA ESTRUTURAL COM BLOCOS DE CONCRETO EM EDIFÍCIOS RESIDENCIAIS
}

\author{
Mayara Amin de Lima, M.Sc. (UFSC); \\ Lisiane Ilha Librelotto, Dra. (UFSC)
}

Devido às alterações de mercado e à introdução de estratégias de racionalização construtiva, novos requisitos foram atribuídos ao projeto, entre eles a necessidade de definição do processo construtivo. O projeto para produção atua como agente de integração entre o produto e o processo de produção, antecipando o como fazer e auxiliando a tomada de decisão antes do momento da execução.

O objetivo principal desta pesquisa é sistematizar o processo de projeto para produção de alvenaria estrutural com blocos de concreto em edifícios residenciais. Trata-se de um estudo de caso aplicado em duas obras de uma construtora do norte do estado de Santa Catarina.

O método deste estudo dividiu-se em quatro etapas: etapa preliminar de pesquisa, diagnóstico, proposição do modelo, aplicação e consolidação. A etapa preliminar de pesquisa consistiu na revisão bibliográfica. $O$ diagnóstico compreendeu a análise da conduta empresarial da construtora, as análises de evidências do estudo de caso (documentação, entrevistas, observação direta e participante), bem como a elaboração e aplicação de check lists de avaliação. A proposta do modelo foi realizada através do método da pesquisa-ação. A etapa de aplicação e consolidação utilizou, além do método da pesquisa-ação, o método PDCA como forma de retroalimentação do processo.

$O$ modelo de processo de projeto para produção consiste em um fluxo cíclico composto de seis etapas: anteprojeto, detalhamento, análise crítica, implantação e acompanhamento, análise de desempenho e retroalimentação. As etapas possuem documentos de registro e controle a fim de iniciar a estruturação de um Banco de Tecnologia Construtiva na empresa.

A aplicação do modelo na construtora resultou na elaboração dos projetos para produção de sequência de alvenaria estrutural e de colocação de peitoril de janelas. No primeiro caso foram testadas as etapas relacionadas à elaboração do projeto, com foco na racionalização construtiva da alvenaria.
Foi possível retroalimentar os demais projetos do empreendimento, evidenciando o potencial compatibilizador do projeto para produção. Foram incrementadas melhorias no modelo e este foi aplicado ao segundo caso. Neste, além das etapas de projeto, houve a aplicação do projeto para produção em obra.

Ao longo da implantação e acompanhamento da utilização notou-se que o projeto para produção atuou como complemento às deficiências do projeto arquitetônico. A segunda aplicação evidenciou possibilidades de melhoria no modelo, tais como a necessidade de vinculação das informações aos setores de Qualidade e Assistência Técnica e a criação de indicadores para medição ao longo da implantação, do acompanhamento e da análise de desempenho do projeto.

Como uma contribuição ao conhecimento a presente pesquisa apresenta um modelo de processo de projeto para produção de alvenaria estrutural com blocos de concreto que promove a racionalização construtiva de etapas críticas da obra de edifícios residenciais e gera informações de retroalimentação como subsídios à elaboração de diretrizes de projetos, em especial o projeto arquitetônico.

\section{REFERÊNCIAS}

LIMA, Mayara Amin de. Sistematização do processo de projeto para produção de alvenaria estrutural com blocos de concreto em edifícios residenciais. 2015. 264 p. Dissertação (Mestrado) - Curso de Pós-graduação em Arquitetura e Urbanismo, Centro Tecnológico, Universidade Federal de Santa Catarina, Florianópolis, 2015. 